\title{
Taking Al Neural Network to Analyze Labor Rights and Labor Disputes
}

\author{
Jia Liu ${ }^{1}$, Ying Yang ${ }^{1}$, Bao-Yao Xiao ${ }^{1}$, Zhi-Tao Huang $^{1}$, Xiao-Hui Nie ${ }^{1}$, Wen-Jie Liu ${ }^{1}$ and Shih-Feng Chang ${ }^{* 1}$ \\ ${ }^{1}$ Nanfang College of Sun Yat-Sen University, Guangzhou, 510970, China
}

\begin{abstract}
Exploring labor rights on the cognition of relationship with labor dispute is not only from the direct role of workers and HR, but also from the fight for labor rights of college students. However, many labor disputes in labor process are mainly related to labor rights. Therefore, we explore the relationship between labor rights and labor disputes, use neural network analysis and questionnaire survey method, and execute AI combining with big data analysis tools to collect first-hand data from two aspects of college students, workers in the industry, HR and labor dispatch personnel. Finally, the results show that: (1) there is a negative correlation between social security and labor disputes; (2) there is a negative correlation between labor safety and labor disputes; (3) there is a negative correlation between wages and labor disputes; (4) there is a negative correlation between labor contract signing and labor disputes; (5) there is a positive correlation between rights awareness and labor disputes.
\end{abstract}

\section{Introduction}

In recent years, with China's social and economic development entering a new era, great changes have taken place in labor relations, workers' awareness of safeguarding their rights is gradually enhanced, the pursuit of their own interests is more diversified, and the number of labor disputes has remained high for a long time, and the handling of labor disputes is increasingly complicated. According to the data of intelligent research consulting, from 2010 to 2019, the agency business scale of accepting workers' appeal cases in China has increased from 558,900 to 934,000 , which is enough to verify that the labor disputes in enterprises are still growing.

In addition, according to the "GuoShuang 2019 Big Data Analysis Report on Labor Dispute Cases" (the total number of judgment documents is 190,832), the cases of labor disputes are mainly concentrated in Guangdong (accounting for 9.69\%), Jiangsu, Beijing (accounting for $7.88 \%$ ), Sichuan and Shandong. It can be seen that labor disputes mostly occur in provinces with more developed economy and more floating population.

Besides, since the outbreak of cowid-19 in 2020, the intensity, breadth, depth and sustainability of the epidemic have had a strong impact on social and economic development, destroyed the normal life and production order, and also made the problem of labor relations more prominent. However, small and medium-sized enterprises are the main body of employment in China, providing more than $80 \%$ of urban labor employment, but they are facing serious problems during the epidemic period. The rights of workers are also affected to varying degrees. There are more and more disputes between employers and employees. However, affected by the epidemic situation, only a small number of labor dispute cases are tried online, and most of them are stagnant. However, after the epidemic situation tends to stabilize, the number of cases may increase sharply.

Under the above background, we attempt to analyze which labor rights are the main causes of labor disputes through the investigation of college students and inservice workers who are going to work in Guangdong Province, and explore the prevention and solutions, so as to play a positive role in building a harmonious labor relationship in society. At the same time, we also provide reference for other provinces and enterprises in China under the new economic form. It can be used for reference to solve labor disputes effectively.

\section{Literature Review}

Domestic research methods of labor dispute are mainly based on literature analysis, comparative analysis and model test. Whether workers are infected COVID-19 pneumonia in their jobs or whether they are "work-related injuries" (Wu Xu, 2020) or whether social security should be compensated will result in labor disputes [4]. After all, it is related to human nature. Due to the lack of social security, labor disputes are often caused by the high attention of high-risk professionals, especially after accidents. At the same time, some first tier cities need to pay enough years for social security to settle down or buy a house locally, but enterprises evade their responsibilities or set unreasonable insurance conditions (Ai-Yu Liu, 2011) [1]. Due to the influence of urbanization and the idea of "entering the city", people's demand for social security has a strong conflict with the practice of enterprises to reduce

"Corresponding author's e-mail: zhangshf@nfu.edu.cn 
costs.

According to the compensatory wage theory, under the same conditions, the wage level of workers engaged in dangerous work is often higher. However, the measurement results show that the two are negatively correlated and not significant, indicating that even if migrant workers engage in dangerous work, they do not get a relatively high income level (Wen-Jiao Xue, 2017; Yang Wang, 2013; Yong Xie, 2008) [3] [5] [6], but the labor disputes caused by them account for a large proportion. Therefore, the more frequent the personal and health violations, the more likely they are to fight for rights (Ai-Yu Liu, 2011) [1].

As an important internal variable in the operation of labor relations, wages have a direct impact on the occurrence of labor disputes. As a form of conflict in the operation of labor relations, labor disputes are bound to be closely related to the legal system of labor relations. Therefore, it is their pursuit to get as much wages as possible, resulting in contradictions and conflicts between the two sides (Shao-Ping Zhang, 2012) [2]. From 1991 to 2009, labor disputes caused by labor remuneration accounted for $29.64 \%$ of all labor disputes. It can be seen that the higher the wage, the less the number of labor disputes. Most of them control the existing resources, so as to reduce the demand for wages. On the contrary, the lower the wage, the more difficult it is to meet the wage, which directly or indirectly leads to a large number of labor disputes. They always feel that their own "labor" is not worth the price. Under the same thing, they feel lost to the wage comparison, so they are not satisfied, and then the possibility of labor disputes is higher.

The law allows employers and workers to agree on the conditions for termination of labor contract. In this case, employers can rely on their strong position in the labor market to agree on harsh conditions for termination of labor contract (Shao-Ping Zhang, 2012) [2]. Therefore, the pre-work game and post-work deduction between workers and capitalists in the labor contract form the main manifestation of labor disputes. Although the signing of a more clear and reasonable labor contract will reduce the number of labor disputes and lasting consumption costs, in fact, the more clear the position and enterprise of the labor contract, the less labor disputes. Moreover, the labor contract has the function of legal basis, which can be directly decided in arbitration and appeal quickly, resulting in the reduction of a large number of similar cases of labor disputes in a short time, or that the duration of labor dispute is not long.

In recent years, the collective cases of labor disputes accepted by Huizhou Intermediate People's Court have increased significantly. Group or series of labor disputes are in the trend of frequent occurrence, especially in the public service industry such as transportation or construction industry. It can be seen that the stronger people's awareness of rights protection, that is, the more they know about labor rights, the more exploitation traps they will find in capital, and the more labor disputes they will cause.

\section{Research Method}

We collect and sort out the domestic and foreign labor disputes in social security, labor safety, wages, labor contract signing and rights awareness as the five influencing factors of labor rights, deeply explore the influence of college students, HR and working workers in the process of fighting for labor rights on labor disputes, and on the basis of the research, construct the theoretical model of this research. In addition, we mainly use use neural network analysis, Python 3 and SPSS 25.0 to explore the collected sample data to verify the theoretical hypothesis.

A total of 227 questionnaires were collected, 4 of which were invalid, and 223 were available. The effective rate was $98.2 \%$. Among them, 200 questionnaires in the student edition were checked, 3 invalid questionnaires were eliminated (all the same options and screening options were randomly filled in, for example, under 18 years old or over 65 years old), 197 valid questionnaires were obtained, and the effective rate was $98.5 \%$. In addition, 23 questionnaires were collected from the industry version, 0 invalid questionnaires were eliminated, and 23 valid questionnaires were obtained, with an effective rate of $100 \%$.

\section{Research Results}

According to the results of the questionnaire data analysis, the respondents were school students, on-the-job workers, labor dispatch personnel and on-the-job HR. A total of 223 valid questionnaires were collected.

Among them, $72.65 \%$ of the respondents' income is below 2,500 yuan, $21.08 \%$ of the respondents' income is between 2,500 yuan and 4,499 yuan, and a few people's salary is higher than 4,500 yuan. Moreover, almost half of the people are not satisfied with their current salary, but $44.84 \%$ think that their current salary is average and acceptable, and less than $8 \%$ are satisfied with their current salary.

However, in the case that half of the people are not very satisfied with their wages, most of the labor disputes caused by their wages are zero, about $90.13 \%$; only a very small number of people have labor disputes caused by their wages, and once labor disputes caused by their wages, accounting for $8.07 \%$.

Otherwise, $30.94 \%$ of them have signed labor contracts with enterprises, about $29.6 \%$ of them have not signed labor contracts with enterprises due to personal reasons, only $8.07 \%$ of them have not signed labor contracts due to enterprises, and $14.35 \%$ of them have not signed labor contracts with enterprises due to other reasons, but $17.04 \%$ of them are still unclear whether they have signed labor contracts with enterprises.

Besides, $77.58 \%$ of the people think it is very important to sign a labor contract, and $18.39 \%$ think it is more important to sign a labor contract. From this viewpoint, we can see that most of the people think that signing a labor contract is important, while only a few people think that signing a labor contract is not important.

However, almost half of the people have a general 
understanding of the labor contract. More than $26 \%$ of the people do not understand the labor contract, while more than $24 \%$ understand the labor contract. Moreover, 35.87\% of the factors in the item "which part of the labor contract do you pay most attention to" thought that labor remuneration was the most important factor, followed by $19.28 \%$ who paid attention to work content and working hours, and finally $17.04 \%$ pointed out that labor protection and working conditions were more important (see Table 1).

\section{Conclusions and Suggestions}

Labor relations management is one of the six major modules of human resources, and it is also the difficulty of HR work in many enterprises. How to properly handle labor disputes and reduce disputes between enterprises and employees has been troubling many enterprises. At the same time, it also greatly affects the relationship between employees and the company, and even some employees leave because of labor disputes. Therefore, it is still an important step to explore the causes of labor disputes and try to reduce the impact.

Based on this situation, we mainly stand in the perspective of workers and the college students who will be employed, starting from the degree of attention of employees to labor rights, discuss the relationship between labor rights and labor disputes, and select five influencing factors, such as social security, labor safety, wages, labor contract signing and rights awareness, through questionnaire survey and statistical analysis, so as to find out the relationship between labor rights and labor disputes. It is confirmed that labor rights are indeed related to labor disputes, that is, the damage of labor rights will increase the occurrence of labor disputes.

Table 1. Which part of labor contract is the most concerned.

\begin{tabular}{|l|c|}
\hline \multicolumn{1}{|c|}{ Item } & Percentage \\
\hline Term of Labor Contract & $7.17 \%$ \\
\hline $\begin{array}{l}\text { Work Content and Working } \\
\text { Hours }\end{array}$ & $19.28 \%$ \\
\hline $\begin{array}{l}\text { Labor Protection and Working } \\
\text { Conditions }\end{array}$ & $17.04 \%$ \\
\hline $\begin{array}{l}\text { Labor Remuneration } \\
\text { Social Insurance Benefits }\end{array}$ & $35.87 \%$ \\
\hline $\begin{array}{l}\text { Enterprise Discipline and Rules } \\
\text { and Regulations }\end{array}$ & $2.24 \%$ \\
\hline $\begin{array}{l}\text { Termination Conditions of Labor } \\
\text { Contract }\end{array}$ & $5.83 \%$ \\
\hline $\begin{array}{l}\text { Liability for Breach of Labor } \\
\text { Contract }\end{array}$ & $4.93 \%$ \\
\hline
\end{tabular}

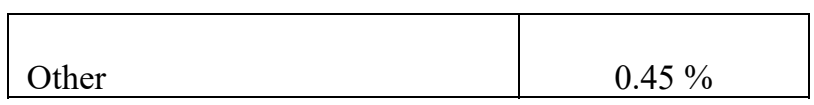

\section{References}

1. Ai-Yu Liu (2011) Research on the damage of labor rights and the choice of action: A comparison between two generations of migrant workers. Journal of Jiangsu Administration College, 1: 68-75.

2. Shao-Ping Zhang (2012) Economic analysis on the influencing factors of labor disputes. Journal of China Institute of Labor Relations, 26(3): 37-41.

3. Wen-Jiao Xue (2017) Research on the influencing factors of labor disputes in Gansu Province. Modern Commerce, 22: 182-183.

4. Wu Xu (2020) COVID-19 pneumonia: Legal issues on employment. Journal of the Open University of Fujian, 4: 75-78.

5. Yang Wang (2013) Analysis of the influencing factors of labor disputes in China during the transition period. Economic and Management Research, 4: 71-80.

6. Yong Xie (2008) An empirical study on the influencing factors of migrant workers' labor rights: A case study in Nanjing. China Population Science, 4: $70-75+98$. 